\title{
The Synthesis and Structure of Palladium 2,4-dimethyl-8-hydroselenoquinolinate
}

\author{
Elga Silina ${ }^{1}$, Yanis Ashaks $^{2}$, Sergey Belyakov ${ }^{3}$, Andrey Tokmakov $^{4}$, Daina Zaruma ${ }^{5}$, \\ ${ }^{1,2,5}$ Institute of Inorganic Chemistry of Riga Technical University, ${ }^{3}$ Latvian Institute of Organic Synthesis, \\ ${ }^{4}$ Institute of Solid State Physics of the University of Latvia
}

\begin{abstract}
The internal complex palladium 2,4-dimethyl-8hydroselenoquinolinate $\mathrm{Pd}_{[}\left[\mathrm{C}_{9} \mathrm{H}_{4}\left(\mathrm{CH}_{3}\right)_{2} \mathrm{NSe}_{2}\right.$ (I) has been synthesized in the course of study of the complexing activity of 8hydroselenoquinoline and investigation of the nature of chemical bond metal-selenium in the five-membered metal-containing ring. $X$-ray diffraction data for I: Monoclinic, space group $\mathbf{P} 2_{1} / \mathbf{n}, a=$ 9.0092(4), $b=16.3290(7), c=14.1073(6) \AA, \beta=106.710(2)^{\circ}, V=$ 1987.7(2) $\AA^{3}, Z=4, R 1=0.0477, w R 2=0.1182$ for 4499 reflections (diffractometer Bruker-Nonius KappaCCD, $\lambda \mathrm{MoK}_{\alpha}$ ).

The crystal structure of the complex $I$ is formed by neutral asymmetric molecules $\mathrm{Pd}\left[\mathrm{C}_{9} \mathrm{H}_{4}\left(\mathrm{CH}_{3}\right)_{2} \mathrm{NSe}\right]_{2}$ in which the central atom palladium is connected bidentically $(\mathrm{Se}, \mathrm{N})$ with two $2,4-$ dimethyl-8-hydroselenoquinoline ligands. The structure of palladium coordination polyhedron is cis-square $(2 \mathrm{Se}+2 \mathrm{~N})$ somewhat tetrahedrally distorted. Dihedral angle between the SePdN / SePdN coordination planes is 20.15(1) ${ }^{\circ}$.

The $\mathrm{Pd}-\mathrm{Se}$ and $\mathrm{Pd}-\mathrm{N}$ bonds are covalent. The transition of trans- (complex $\mathrm{Pd}\left(\mathrm{C}_{9} \mathrm{H}_{6} \mathrm{NSe}\right)_{2}$ (II) to cis-coordination (complex I) causes the weakening of the $\mathrm{Pd}-\mathrm{N}$ bonds (compare 2.162(5) and $2.159(5) \AA$ (I), $2.065(3) \AA$ (II) ).
\end{abstract}

Keywords: palladium 2,4-dimethyl-8-hydroselenoquinolinate, palladium coordination compounds, synthesis of 8hydroselenoquinolinates, $\mathrm{X}$-ray diffraction analysis

\section{INTRODUCTION}

In the course of studies concerning the metal-sulphur bond in the internal complexes of transition and non-transition elements, at the Laboratory of Internal Complexes of INC of RTU a plenty of 8-mercaptoquinoline and its derivatives complexes have been synthesized and structurally investigated earlier [1]. The obtained results have been compared with the structures of the corresponding 8-hydroxyquinolinate.

The synthesis and X-ray structural investigations of the internal complexes of 8-hydroselenoquinoline and its derivatives have been continued in order to elucidate the character of the bonds $\mathrm{M}-\mathrm{Se}(\mathrm{O}, \mathrm{S})$ and their dynamics in the mutually similar five-membered metal-containing cyclic compounds belonging to one and the same VI group. The similar systematic structural investigations of the internal complex compounds are not known in the literature up to now. Therefore, the issue concerning the coordination abilities of the selenium (II) atom as a ligand atom, as well as the experimental determination of the length of the valence bonds $\mathrm{M}-\mathrm{Se}$ in the internal complexes is a matter of principle. Up to now, we have established the molecular and crystal structure of 8-hydroselenoquinoline complexes with platinum [2], palladium [3], cadmium [2], zinc [4], mercury [5], antimony
[6] and bismuth [7] as well as platinum, cadmium, zinc, mercury, antimony and bismuth 2-methyl-8hydroselenoquinolinates [8-13] and zinc and cadmium 2phenyl-8-hydroselenoquinolinates [14-15]. In the crystal structures containing the 2-methyl- and 2-phenylsubstituted ligands, the effect of position and nature of the substituent on the molecular structure of the complex has been observed. The changes in the molecular structure, mainly, in the coordination environment of the central atom are different in the complexes of the transition and non-transition metals. The determined structure of palladium 2,4-dimethyl-8-hydroselenolquinolinates $\quad \mathrm{Pd}\left[\mathrm{C}_{9} \mathrm{H}_{4}\left(2-\mathrm{CH}_{3}, 4-\mathrm{CH}_{3}\right) \mathrm{NSe}\right]_{2} \quad$ (I) being considered in the present research will be able to exert the effect of the summary action of the two electron-donor substituents in the 8-hydroselenoquinoline ligand on the coordination environment of the complexing palladium atom.

\section{EXPERIMENTAL SECTION}

\section{Synthesis}

Dissolve $0.1 \mathrm{~g}(0.00056 \mathrm{mmol})$ of $\mathrm{PdCl}_{2}$ in $1 \mathrm{ml}$ of halfconcentrated hydrochloric acid and add $10 \mathrm{ml}$ of water. Dissolve $0.3 \mathrm{~g}(0.00064 \mathrm{mmol})$ of 2,2',4,4'-tetramethyl-8,8'diquinolyl diselenide in $2 \mathrm{ml}$ of half-concentrated hydrochloric acid, add $1 \mathrm{ml}$ of $50 \% \mathrm{H}_{3} \mathrm{PO}_{2}$ and allow to stand for $10 \mathrm{~min}$. Then add $10 \mathrm{ml}$ of ethanol, $1 \mathrm{ml}$ of saturated sodium acetate solution and, finally, add the palladium solution that was prepared earlier. The deposited red deposit filter wash with water and dry in the air. Yield $0.27 \mathrm{~g}(83 \%)$.

Found, \%: C 46.25; $\mathrm{H} 3.58 ; \mathrm{N} 4.75 . \mathrm{C}_{22} \mathrm{H}_{20} \mathrm{~N}_{2} \mathrm{Se}_{2} \mathrm{Pd}$.

Calculated, \%: C 45.84; H 3.49; N 4.85 .

The single crystals were grown up from the chloroform solution.

\section{X-ray Diffraction Analysis}

$\mathrm{X}$-ray diffraction data were collected from a dark red single crystal (imperfect form). The Bruker-Nonius KappaCCD automatic diffractometer was used. The structure was solved by the direct method with a subsequent Fourier synthesis and refined by the least squares matrix analysis using SHELXL package in the full-matrix anisotropic approximation for nonhydrogen atoms, taking into account the coordinates of the hydrogen atoms. Hydrogen atoms were located both from the differential synthesis and from idealized position and refined using a riding model [16, 17]. Calculations were performed using the software [18]. 
The crystallographic characteristics and the results of the structure refinement are listed in Table 1; the final coordinates and thermal parameters of the basic atoms of structure I - in Table 2; the selected geometric characteristics of complex I in Table 3 and 4.

TABLE 1

CRYSTALlOGRAPHIC PARAMETERs, EXPERIMENTAL AND STRUCTURE REFINEMENT DETAILS FOR STRUCTURE I

\begin{tabular}{|c|c|}
\hline Parameter & Value \\
\hline Empirical formula & $\mathrm{C}_{22} \mathrm{H}_{20} \mathrm{~N}_{2} \mathrm{Se}_{2} \mathrm{Pd}$ \\
\hline Molecular mass & 576.72 \\
\hline Temperature, $\mathrm{K}$ & 293(2) \\
\hline Crystal system & Monoclinic \\
\hline Space group & $\mathrm{P} 2{ }_{1} / \mathrm{n}$ \\
\hline \multicolumn{2}{|l|}{ Unit cell parameters: } \\
\hline$a, \AA$ & $9.0092(4)$ \\
\hline$b, \AA$ & $16.3290(7)$ \\
\hline $\mathrm{c}, \AA$ & $14.1073(6)$ \\
\hline$\alpha, \operatorname{deg}$ & 90 \\
\hline$\beta$, deg & $106.710(2)$ \\
\hline$\gamma$, deg & 90 \\
\hline$V, \AA^{3}$ & $1987.7(2)$ \\
\hline $\mathrm{Z}$ & 4 \\
\hline$\rho_{\text {calc, }} \mathrm{g} / \mathrm{cm}^{3}$ & 1.927 \\
\hline$\mu, \mathrm{mm}-1$ & 4.605 \\
\hline $\mathrm{F}(000)$ & 1120 \\
\hline Crystal dimensions, mm & $0.17 \times 0.13 \times 0.12$ \\
\hline Crystal colour & Dark red \\
\hline Data collection & KappaCCD \\
\hline Scan mode & $\theta / 2 \theta$ \\
\hline $2 \theta_{\text {max. }}$, deg & 55.0 \\
\hline Radiation type & $\operatorname{Mo} K_{\alpha}$ \\
\hline Wavelength, $\AA$ & 0.71073 \\
\hline Reflection index range & $\begin{array}{l}-11<=\mathrm{h}<=11,-19<=\mathrm{k}<=21, \\
-18<=\mathrm{l}<=18\end{array}$ \\
\hline Absorption correction & None \\
\hline Reflections collected & 8004 \\
\hline $\begin{array}{l}\text { Independent reflections, } \\
{[\mathrm{R}(\text { int })=0.0439]}\end{array}$ & 4499 \\
\hline Refinement method & $\begin{array}{l}\text { Full-matrix least-squares } \\
\text { calculation on } \mathrm{F}^{2}\end{array}$ \\
\hline Parameters refined & 244 \\
\hline Final $\mathrm{R}$ for $\mathrm{I}>2 \sigma\left(\mathrm{I}_{\mathrm{obs} .}\right)$ & $\mathrm{R} 1=0.0477, \mathrm{wR} 2=0.1128$ \\
\hline $\mathrm{R}$ for all reflections & $\mathrm{R} 1=0.0914, \mathrm{wR} 2=0.1375$ \\
\hline Largest diff. peak and hole, e/ $\AA^{3}$ & 0.609 and -0.790 \\
\hline
\end{tabular}

TABLE 2

ATOMIC COORDINATES $\left(\times 10^{4}, \times 10^{3}\right.$ FOR H $)$ AND DISPLACEMENT PARAMETERS $\left(\mathrm{IN} \AA^{2}, \times 10^{3}\right)$ OF COMPLEX I

\begin{tabular}{|c|c|c|c|c|}
\hline Atom & $\mathrm{x}$ & $\mathrm{y}$ & $\mathrm{z}$ & $\mathrm{U}_{\mathrm{eq}}$ \\
\hline $\operatorname{Pd}(1)$ & $2235(1)$ & $1607(1)$ & $2855(1)$ & $41(1)$ \\
\hline $\operatorname{Se}(1 \mathrm{a})$ & 1988(1) & $587(1)$ & $3980(1)$ & $57(1)$ \\
\hline $\operatorname{Se}(1 b)$ & $2458(1)$ & $537(1)$ & $1782(1)$ & 61(1) \\
\hline $\mathrm{C}(2)$ & $4173(7)$ & $3372(4)$ & $3434(4)$ & $45(1)$ \\
\hline $\mathrm{N}(1 \mathrm{a})$ & $2639(6)$ & $2420(3)$ & 4114(3) & $38(1)$ \\
\hline$C(2 a)$ & $374(7)$ & $3133(4)$ & 4199(4) & $41(1)$ \\
\hline$C(3 a)$ & $3434(8)$ & $3685(4)$ & $4980(5)$ & $49(2)$ \\
\hline$C(4 a)$ & $2756(8)$ & 3489(4) & $5723(5)$ & $49(2)$ \\
\hline $\mathrm{C}(5 \mathrm{a})$ & 1441(8) & $2405(5)$ & $6428(5)$ & $57(2)$ \\
\hline$C(6 a)$ & $949(9)$ & $1633(6)$ & $6409(5)$ & $63(2)$ \\
\hline $\mathrm{C}(7 \mathrm{a})$ & $1062(8)$ & $1080(5)$ & $5667(5)$ & $55(2)$ \\
\hline $\mathrm{C}(8 \mathrm{a})$ & $1636(8)$ & $1348(4)$ & $4920(5)$ & $48(2)$ \\
\hline $\mathrm{C}(9 \mathrm{a})$ & $2100(7)$ & $2165(4)$ & 4890(4) & $43(1)$ \\
\hline$C(10 a)$ & 2092(7) & 2706(4) & $5693(4)$ & $43(1)$ \\
\hline$C(4)$ & $2818(10)$ & 4071(6) & $6540(6)$ & $69(2)$ \\
\hline $\mathrm{N}(1 \mathrm{~b})$ & $1859(6)$ & $2368(3)$ & $1556(4)$ & $41(1)$ \\
\hline$C(2 b)$ & $1154(7)$ & $3089(4)$ & $1429(4)$ & $43(1)$ \\
\hline$C(3 b)$ & $1090(8)$ & $3592(4)$ & 609(4) & $46(2)$ \\
\hline $\mathrm{C}(4 \mathrm{~b})$ & $1797(8)$ & $3372(4)$ & $-89(5)$ & $48(2)$ \\
\hline$C(5 b)$ & $3151(8)$ & $2246(5)$ & $-731(4)$ & $51(2)$ \\
\hline $\mathrm{C}(6 \mathrm{~b})$ & $3644(9)$ & $1453(5)$ & $-656(5)$ & $57(2)$ \\
\hline$C(7 b)$ & $3470(8)$ & $942(5)$ & $88(5)$ & $58(2)$ \\
\hline$C(8 b)$ & $2860(7)$ & $1243(4)$ & $821(4)$ & $44(1)$ \\
\hline $\mathrm{C}(9 \mathrm{~b})$ & $2417(7)$ & $2075(4)$ & $799(4)$ & $41(1)$ \\
\hline$C(10 b)$ & $2472(7)$ & $2576(4)$ & $-18(4)$ & $45(2)$ \\
\hline $\mathrm{C}\left(2^{\prime}\right)$ & $341(7)$ & $3379(4)$ & 2165(4) & $46(1)$ \\
\hline$C\left(4^{\prime}\right)$ & $1778(9)$ & $3923(5)$ & $-939(6)$ & $65(2)$ \\
\hline $\mathrm{H}(2 \mathrm{a})$ & 4041(7) & 2944(4) & 2950(4) & 68 \\
\hline $\mathrm{H}(2 \mathrm{~b})$ & $5257(7)$ & $3454(4)$ & $3751(4)$ & 68 \\
\hline $\mathrm{H}(2 \mathrm{c})$ & $3727(7)$ & $3870(4)$ & $3115(4)$ & 68 \\
\hline $\mathrm{H}(3 \mathrm{a})$ & $3932(8)$ & 4186(4) & 4999(5) & 58 \\
\hline $\mathrm{H}(5 \mathrm{a})$ & $1356(8)$ & $2752(5)$ & 6932(5) & 69 \\
\hline $\mathrm{H}(6 \mathrm{a})$ & $520(9)$ & $1456(6)$ & $6899(5)$ & 75 \\
\hline $\mathrm{H}(7 \mathrm{a})$ & $751(8)$ & $538(5)$ & 5683(5) & 66 \\
\hline $\mathrm{H}(4 \mathrm{a})$ & $2297(10)$ & $3838(6)$ & 6981(6) & 104 \\
\hline $\mathrm{H}(4 \mathrm{~b})$ & $2318(10)$ & $4574(6)$ & $6272(6)$ & 104 \\
\hline $\mathrm{H}(4 \mathrm{c})$ & $3880(10)$ & 4179(6) & \begin{tabular}{|l|}
$6896(6)$ \\
\end{tabular} & 104 \\
\hline $\mathrm{H}(3 \mathrm{~b})$ & $554(8)$ & $4085(4)$ & 541(4) & 55 \\
\hline $\mathrm{H}(5 \mathrm{~b})$ & $3258(8)$ & $2572(5)$ & $-1248(4)$ & 61 \\
\hline $\mathrm{H}(6 \mathrm{~b})$ & $4110(9)$ & $1249(5)$ & $-1116(5)$ & 68 \\
\hline $\mathrm{H}(7 \mathrm{~b})$ & $3762(8)$ & $395(5)$ & $99(5)$ & 70 \\
\hline $\mathrm{H}\left(2^{\prime} 1\right)$ & $475(7)$ & 2981(4) & $2683(4)$ & 69 \\
\hline $\mathrm{H}\left(2^{\prime} 2\right)$ & $-744(7)$ & $3447(4)$ & 1837(4) & 69 \\
\hline $\mathrm{H}\left(2^{\prime} 3\right)$ & $774(7)$ & $3892(4)$ & 2442(4) & 69 \\
\hline $\mathrm{H}\left(4^{\prime} 1\right)$ & $2330(9)$ & $3667(5)$ & $-1349(6)$ & 97 \\
\hline $\mathrm{H}\left(4^{\prime} 2\right)$ & $2267(9)$ & $4433(5)$ & $-692(6)$ & 97 \\
\hline $\mathrm{H}\left(4^{\prime} 3\right)$ & $726(9)$ & $4022(5)$ & $-1321(6)$ & 97 \\
\hline
\end{tabular}




\section{RESULTS AND DISCUSSION}

The crystal structure of complex I consists of the neutral asymmetric molecules $\mathrm{Pd}\left[\mathrm{C}_{9} \mathrm{H}_{4}\left(2-\mathrm{CH}_{3}, 4-\mathrm{CH}_{3}\right) \mathrm{NSe}\right]_{2}$. The common view of the molecule with the assignment of atoms is shown in Fig. 1.

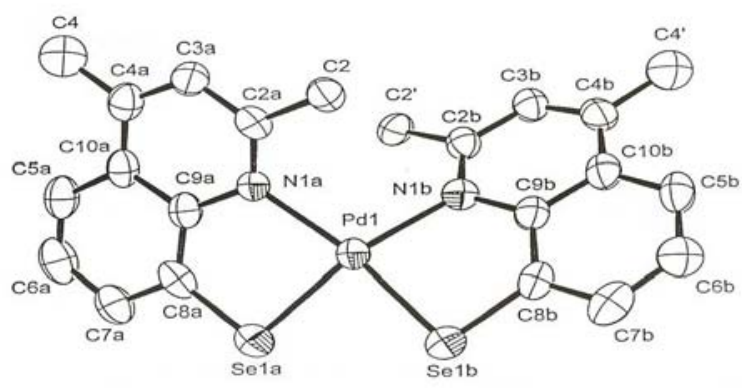

Fig. 1. Molecular structure of $\mathrm{Pd}\left[\mathrm{C}_{9} \mathrm{H}_{4}\left(\mathrm{CH}_{3}\right)_{2} \mathrm{NSe}\right]_{2}$

The palladium atoms occupy the common places in the elementary cell, the atoms of selenium and nitrogen are bidentatically coordinated by the two non-identical ligands of 2,4-dimethyl-8-hydroselenoquinoline and are included in two metal-containing rings. The bonds $\mathrm{Pd}-\mathrm{Se}\left(\mathrm{l}_{\mathrm{aver}}=2.357 \AA\right)$ are nearly equal (Table 3 ).

TABLE 3

SELECTED BOND LENGTH OF COMPLEX I

\begin{tabular}{|c|c|c|c|}
\hline Bond & $1, \AA$ & Bond & $1, \AA$ \\
\hline $\operatorname{Pd}(1)-N(1 b)$ & $2.159(5)$ & $\mathrm{C}(7 \mathrm{a})-\mathrm{C}(8 \mathrm{a})$ & $1.372(9)$ \\
\hline $\operatorname{Pd}(1)-N(1 a)$ & $2.162(5)$ & $\mathrm{C}(8 \mathrm{a})-\mathrm{C}(9 \mathrm{a})$ & $1.403(10)$ \\
\hline $\operatorname{Pd}(1)-\operatorname{Se}(1 a)$ & $2.3552(8)$ & $\mathrm{C}(9 \mathrm{a})-\mathrm{C}(10 \mathrm{a})$ & $1.438(9)$ \\
\hline $\operatorname{Pd}(1)-\operatorname{Se}(1 b)$ & $2.3587(9)$ & $\mathrm{N}(1 \mathrm{~b})-\mathrm{C}(2 \mathrm{~b})$ & $1.325(8)$ \\
\hline $\operatorname{Se}(1 a)-C(8 a)$ & $1.909(7)$ & $\mathrm{N}(1 \mathrm{~b})-\mathrm{C}(9 \mathrm{~b})$ & $1.390(8)$ \\
\hline $\mathrm{Se}(1 \mathrm{~b})-\mathrm{C}(8 \mathrm{~b})$ & $1.893(7)$ & $C(2 b)-C(3 b)$ & $1.405(9)$ \\
\hline$C(2)-C(2 a)$ & $1.510(8)$ & $\mathrm{C}(2 \mathrm{~b})-\mathrm{C}\left(2^{\prime}\right)$ & $1.508(8)$ \\
\hline $\mathrm{N}(1 \mathrm{a})-\mathrm{C}(2 \mathrm{a})$ & $1.328(8)$ & $C(3 b)-C(4 b)$ & $1.366(9)$ \\
\hline $\mathrm{N}(1 \mathrm{a})-\mathrm{C}(9 \mathrm{a})$ & $1.383(7)$ & $C(4 b)-C(10 b)$ & $1.427(10)$ \\
\hline$C(2 a)-C(3 a)$ & $1.412(9)$ & $C(4 b)-C\left(4^{\prime}\right)$ & $1.495(10)$ \\
\hline$C(3 a)-C(4 a)$ & $1.393(9)$ & $C(5 b)-C(6 b)$ & $1.364(10)$ \\
\hline$C(4 a)-C(10 a)$ & $1.408(10)$ & $C(5 b)-C(10 b)$ & $1.424(9)$ \\
\hline $\mathrm{C}(4 \mathrm{a})-\mathrm{C}(4)$ & $1.482(10)$ & $C(6 b)-C(7 b)$ & $1.384(11)$ \\
\hline$C(5 a)-C(6 a)$ & $1.333(11)$ & $C(7 b)-C(8 b)$ & $1.392(9)$ \\
\hline$C(5 a)-C(10 a)$ & $1.418(9)$ & $C(8 b)-C(9 b)$ & $1.414(9)$ \\
\hline$C(6 a)-C(7 a)$ & $1.409(11)$ & $C(9 b)-C(10 b)$ & $1.426(9)$ \\
\hline
\end{tabular}

They possess the expressed covalent nature, as their lengths are less than the sum of the covalent radii of the corresponding atoms $\left(\mathrm{R}_{\mathrm{Pd}}+\mathrm{R}_{\mathrm{Se}}=2,534 \AA\right.$ [19]). The covalent nature of the PdSe bonds is expressed stronger than in the complex $\mathrm{Pd}\left(\mathrm{C}_{9} \mathrm{H}_{6} \mathrm{NSe}\right)_{2}$ (II), in which the bond lengths in the centrosymmetric trans-square coordination of palladium constitute 2.404(4) $\AA$. The transfer from the planar trans(complex II with non-substituted ligands) to cis-square coordination (complex I) is accompanied by the decrease in covalence and in elongation of the Pd-N bond from $2.065 \AA$ (complex II) to $1_{\text {aver. }}=2.161 \AA$ (Table 4 ) in complex I (the sum of covalent radii $\mathrm{R}_{\mathrm{Pd}}+\mathrm{R}_{\mathrm{N}}=2.102 \AA$ [19]). This probably is due to the influence of the $4-\mathrm{CH}_{3}$ groups. It is necessary to emphasize that in platinum 2-methyl-8-hydroselenoquinolinate, in which the coordination polyhedron of the platinum atom is a trans-square $(2 \mathrm{Se}+2 \mathrm{~N})$ with the Pt-N, bond length and the angle NPtN are not changed in contrast to $\mathrm{Pt}\left(\mathrm{C}_{9} \mathrm{H}_{6} \mathrm{NSe}\right)_{2}[2]$.

TABLE 4

SELECTED BOND ANGLES OF COMPLEX I

\begin{tabular}{|c|c|c|c|}
\hline Angle & $\omega$, deg & Angle & $\omega, \operatorname{deg}$ \\
\hline $\mathrm{N}(1 \mathrm{~b}) \operatorname{Pd}(1) \mathrm{N}(1 \mathrm{a})$ & 107.0(2) & $\mathrm{C}(8 \mathrm{a}) \mathrm{C}(9 \mathrm{a}) \mathrm{C}(10 \mathrm{a})$ & $119.4(6)$ \\
\hline $\mathrm{N}(1 \mathrm{~b}) \operatorname{Pd}(1) \operatorname{Se}(1 \mathrm{a})$ & 163.1(1) & $C(4 a) C(10 a) C(5 a)$ & $123.6(6)$ \\
\hline $\mathrm{N}(1 \mathrm{a}) \operatorname{Pd}(1) \operatorname{Se}(1 \mathrm{a})$ & $84.65(13)$ & $\mathrm{C}(4 a) \mathrm{C}(10 \mathrm{a}) \mathrm{C}(9 \mathrm{a})$ & $119.0(6)$ \\
\hline $\mathrm{N}(1 \mathrm{~b}) \operatorname{Pd}(1) \operatorname{Se}(1 \mathrm{~b})$ & $84.45(14)$ & $\mathrm{C}(5 \mathrm{a}) \mathrm{C}(10 \mathrm{a}) \mathrm{C}(9 \mathrm{a})$ & $117.4(7)$ \\
\hline $\mathrm{N}(1 \mathrm{a}) \operatorname{Pd}(1) \operatorname{Se}(1 \mathrm{~b})$ & 163.1(1) & $C(2 b) N(1 b) C(9 b)$ & $117.9(5)$ \\
\hline $\operatorname{Se}(1 \mathrm{a}) \operatorname{Pd}(1) \operatorname{Se}(1 \mathrm{~b})$ & $87.14(3)$ & $\mathrm{C}(2 \mathrm{~b}) \mathrm{N}(1 \mathrm{~b}) \operatorname{Pd}(1)$ & $125.3(4)$ \\
\hline $\mathrm{C}(8 \mathrm{a}) \mathrm{Se}(1 \mathrm{a}) \operatorname{Pd}(1)$ & $94.3(2)$ & $\mathrm{C}(9 \mathrm{~b}) \mathrm{N}(1 \mathrm{~b}) \operatorname{Pd}(1)$ & $116.8(4)$ \\
\hline $\mathrm{C}(8 \mathrm{~b}) \mathrm{Se}(1 \mathrm{~b}) \operatorname{Pd}(1)$ & $94.4(2)$ & $\mathrm{N}(1 \mathrm{~b}) \mathrm{C}(2 \mathrm{~b}) \mathrm{C}(3 \mathrm{~b})$ & $122.3(6)$ \\
\hline$C(2 a) N(1 a) C(9 a)$ & $118.2(5)$ & $\mathrm{N}(1 \mathrm{~b}) \mathrm{C}(2 \mathrm{~b}) \mathrm{C}\left(2^{\prime}\right)$ & $119.6(5)$ \\
\hline $\mathrm{C}(2 \mathrm{a}) \mathrm{N}(1 \mathrm{a}) \mathrm{Pd}(1)$ & 125.1(4) & $\mathrm{C}(3 \mathrm{~b}) \mathrm{C}(2 \mathrm{~b}) \mathrm{C}\left(2^{\prime}\right)$ & $118.0(6)$ \\
\hline $\mathrm{C}(9 \mathrm{a}) \mathrm{N}(1 \mathrm{a}) \operatorname{Pd}(1)$ & $116.8(4)$ & $C(4 b) C(3 b) C(2 b)$ & $121.5(6)$ \\
\hline $\mathrm{N}(1 \mathrm{a}) \mathrm{C}(2 \mathrm{a}) \mathrm{C}(3 \mathrm{a})$ & $122.4(6)$ & $C(3 b) C(4 b) C(10 b)$ & $117.8(6)$ \\
\hline $\mathrm{N}(1 \mathrm{a}) \mathrm{C}(2 \mathrm{a}) \mathrm{C}(2)$ & $119.3(6)$ & $C(3 b) C(4 b) C\left(4^{\prime}\right)$ & $121.4(7)$ \\
\hline$C(3 a) C(2 a) C(2)$ & $118.3(6)$ & $\mathrm{C}(10 \mathrm{~b}) \mathrm{C}(4 \mathrm{~b}) \mathrm{C}\left(4^{\prime}\right)$ & $120.7(6)$ \\
\hline $\mathrm{C}(4 \mathrm{~A}) \mathrm{C}(3 \mathrm{~A}) \mathrm{C}(2 \mathrm{a})$ & $120.9(6)$ & $C(6 b) C(5 b) C(10 b)$ & $120.0(7)$ \\
\hline$C(3 a) C(4 a) C(10 a)$ & $117.3(6)$ & $C(5 b) C(6 b) C(7 b)$ & $121.7(7)$ \\
\hline $\mathrm{C}(3 \mathrm{a}) \mathrm{C}(4 \mathrm{a}) \mathrm{C}(4)$ & $120.7(7)$ & $\mathrm{C}(6 \mathrm{~b}) \mathrm{C}(7 \mathrm{~b}) \mathrm{C}(8 \mathrm{~b})$ & $120.4(7)$ \\
\hline $\mathrm{C}(10 \mathrm{a}) \mathrm{C}(4 \mathrm{a}) \mathrm{C}(4)$ & $121.8(6)$ & $\mathrm{C}(7 \mathrm{~b}) \mathrm{C}(8 \mathrm{~b}) \mathrm{C}(9 \mathrm{~b})$ & $119.5(6)$ \\
\hline $\mathrm{C}(6 \mathrm{a}) \mathrm{C}(5 \mathrm{a}) \mathrm{C}(10 \mathrm{a})$ & 121.2(7) & $C(7 b) C(8 b) \operatorname{Se}(1 b)$ & $121.0(6)$ \\
\hline $\mathrm{C}(5 \mathrm{a}) \mathrm{C}(6 \mathrm{a}) \mathrm{C}(7 \mathrm{a})$ & $121.7(7)$ & $\mathrm{C}(9 \mathrm{~b}) \mathrm{C}(8 \mathrm{~b}) \mathrm{Se}(1 \mathrm{~b})$ & $119.4(4)$ \\
\hline $\mathrm{C}(8 \mathrm{a}) \mathrm{C}(7 \mathrm{a}) \mathrm{C}(6 \mathrm{a})$ & $119.4(7)$ & $\mathrm{N}(1 \mathrm{~b}) \mathrm{C}(9 \mathrm{~b}) \mathrm{C}(8 \mathrm{~b})$ & $118.5(5)$ \\
\hline $\mathrm{C}(7 \mathrm{a}) \mathrm{C}(8 \mathrm{a}) \mathrm{C}(9 \mathrm{a})$ & $120.5(7)$ & $\mathrm{N}(1 \mathrm{~b}) \mathrm{C}(9 \mathrm{~b}) \mathrm{C}(10 \mathrm{~b})$ & $121.9(6)$ \\
\hline $\mathrm{C}(7 \mathrm{a}) \mathrm{C}(8 \mathrm{a}) \mathrm{Se}(1 \mathrm{a})$ & $120.1(6)$ & $\mathrm{C}(8 \mathrm{~b}) \mathrm{C}(9 \mathrm{~b}) \mathrm{C}(10 \mathrm{~b})$ & $119.6(6)$ \\
\hline $\mathrm{C}(9 \mathrm{a}) \mathrm{C}(8 \mathrm{a}) \mathrm{Se}(1 \mathrm{a})$ & 119.1(5) & $\mathrm{C}(5 \mathrm{~b}) \mathrm{C}(10 \mathrm{~b}) \mathrm{C}(9 \mathrm{~b})$ & $118.4(7)$ \\
\hline $\mathrm{N}(1 \mathrm{a}) \mathrm{C}(9 \mathrm{a}) \mathrm{C}(8 \mathrm{a})$ & 119.1(6) & $C(5 b) C(10 b) C(4 b)$ & $123.8(6)$ \\
\hline $\mathrm{N}(1 \mathrm{a}) \mathrm{C}(9 \mathrm{a}) \mathrm{C}(10 \mathrm{a})$ & $121.4(6)$ & $C(9 b) C(10 b) C(4 b)$ & $117.8(6)$ \\
\hline
\end{tabular}

The chelate angles SePdN in complex I (Table 4) are equal within the limits of the error $\left(\omega_{\text {aver. }}=84.55^{\circ}\right)$. The coordination polyhedron of the palladium atom in complex I is a slightly tetrahedrally distorted cis-square $(2 \mathrm{Se}+2 \mathrm{~N})$. The degree of distortion of the planar environment of the palladium atom is characterized by the values of the diagonal angles $\operatorname{SePdN}\left(\omega_{\text {aver. }}=163.1^{\circ}\right)$ (Table 4$)$ and by the dihedral angle between the coordination planes SePdN amounting to $20.15(1)^{\circ}$.

The values of deviations of the palladium, selenium and nitrogen atoms from the mean square show that the mentioned atoms of palladium, selenium are located approximately in the same plane. The nitrogen and carbon 
atoms of the $\mathrm{CH}_{3}$ groups are remote from this plane and are located in the opposite sides. The interligand repulsion of the selenium atom and $\mathrm{CH}_{3}$ group in the cis-square coordination of the palladium atom is decreased due to the essential deviations of the palladium, selenium, carbon (methyl) atoms from the planes of the corresponding quinoline nuclei. The distance Pd...C(2) equals 3.344(5) and 3.357(5) $\AA$.

The Se-C bond (Table 4) $\left(1_{\text {aver. }}=1.901 \AA\right)$ also possesses the covalent nature (the sum of the corresponding covalent radii $\mathrm{R}_{\mathrm{Se}}+\mathrm{R}_{\mathrm{C}}=1.933 \AA$ ) and is near to the value $1.893 \AA$ given in [20] for the $\mathrm{Se}(\mathrm{II})-\mathrm{Csp}^{2}$ fragment. The valence angles $\operatorname{PdSeC}\left(\omega_{\text {aver. }}=94.35^{\circ}\right)$ (Table 4$)$ give the evidence on the octahedral disposition of the electrons of the external electron layer of the selenium atom and on the additional strengthening of the Pd-Se bond due to the direct donoracceptor $\pi$-bond [21].

The steric hindrance due to the presence of the $2-\mathrm{CH}_{3}$ group in the ligands and the tendency to preserve the approximate planarity of the coordination knot $(\mathrm{Pd}+2 \mathrm{Se}+2 \mathrm{~N})$ at the formation of the complex is accompanied by the bend of the five-membered metal-containing rings -Pd-Se-C(8)$\mathrm{C}(9)-\mathrm{N}$ - along the line Se...N. The dihedral angles of the bending of the metal-containing rings equal 22.56 and $23.44^{\circ}$, i.e., one of the greatest bending occurrences in the metal-containing rings, consequently, the five-membered metal-containing rings $-\mathrm{Pd}-\mathrm{Se}-\mathrm{C}(8)-\mathrm{C}(9)-\mathrm{N}$ - in complex I possess the "sloped" configuration.

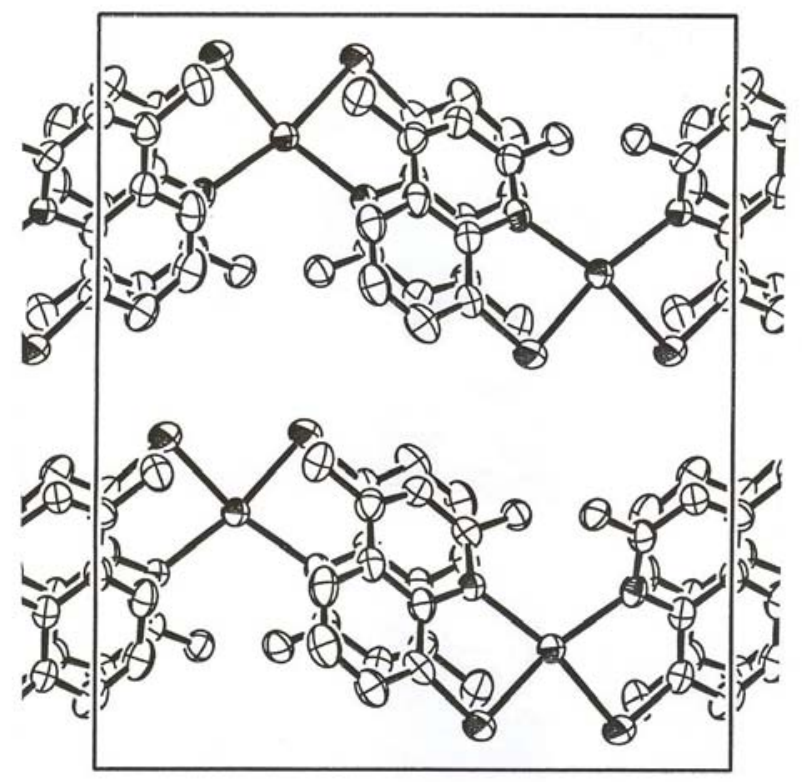

Fig. 2. The packing of complex I in the unit cell, projected onto the (001) plane

The dihedral angle between the planes of the quinoline nuclei is increased up to $38.71^{\circ}$ due to the bending of the metal containing rings. The spatial disposition of the ligands in the molecule of palladium 2-methyl-8mercaptoquinolinate is shown in Fig. 2. The quinoline rings are planar in the both ligands within the limits of error $3 \sigma$. The structure of the quinoline rings is usual: the bonds of the type $\mathrm{N}(1)-\mathrm{C}(2)\left(\mathrm{l}_{\text {aver. }}=1.327 \AA\right)$ are essentially shorter than the bonds of the type N(1)-C(9) $\left(l_{\text {aver. }}=1.387 \AA\right)$ and exert the trend to double bonding (the length of the sesquibond Caryl$\mathrm{N}$ equals 1.333-1.345 $\AA$ [20]. The alternating bonds $\mathrm{C}(3)$ $\mathrm{C}(4), \mathrm{C}(5)-\mathrm{C}(6) \mathrm{C}(7)-\mathrm{C}(8)$ (Table 4) are shortened. The central bond of type $\mathrm{C}(9)-\mathrm{C}(10)\left(1_{\text {aver. }}=1.418 \AA\right)$ occurs to be the most lengthened one. The angles CCC differ from $120^{\circ}$ insignificantly $( \pm 2.5)$. The value of the angle $\mathrm{C}(2) \mathrm{N}(1) \mathrm{C}(9)$ $\left(\omega_{\text {aver. }}=118.1^{\circ}\right)$ confirms the participation of the nitrogen atom in the donor-acceptor bond Pd-N.

Complex I is geometrically packed in the crystal structure in layers parallel to the xy plane. In this plane, there are the palladium atoms, and between them the layers of the parallel ligands occur (Fig. 2). The distance between the centrosymmetrically bonded planes of the quinoline rings is $3.733 \AA$.

Complex I has no isostructural analogue in the group of studied 8-mercaptoquinolinate.

\section{CONCLUSIONS}

Using the X-ray structural analysis method, the structure of complex I has been elucidated. Our studies have demonstrated that the introduction of the $2-\mathrm{CH}_{3}$ and $4-\mathrm{CH}_{3}$ groups in the 8-hydroselenoquinoline ligand causes the changes of both the molecular and crystal structure of the complex.

In complex I, if compared with complex II, the disproportion of the Pd-Se and Pd-N bond lengths occurs. The type of the coordination polyhedron of the central palladium atom and the spatial dislocation of the complex are also changed.

\section{REFERENCES}

1. Bankovskij U. A. Himia vnutrikompleksnyh soedinenij merkaptohinolina i ego proizvodnyx. Riga: Zinatne, 1978, 488 s.

2. Pech L., Belsky V., Stash A., Ashsks J., Silina E., Bankovsky Yu. Structure and comparative crystallochemical analysis of platinum and cadmium 8-hydroselenolquinolinates. Latvijas Kimijas Zurnāls, 2003, Nr. 3, 237. - 246. lpp.

3. Silins E. A., Asaks A. V., Belakov S. B., Pec L. A., Bankovskij U. A. Sintez i stroenie 8-selenolhinolinata palladia $\mathrm{Pd}\left(\mathrm{C}_{9} \mathrm{H}_{6} \mathrm{NSe}_{2}\right.$. Himia geterocikl. soed., 2006, № 3, c. 396.-402.[Chem. Heterocycl. Comp., 2006, vol. 42, N 3, p. 352.-357.]

4. Pech L., Ashaks J., Belsky V., Stash A., Silina E., Bankovsky Yu. Xray study of zinc 8-hydroselenoquinolinate and comparative crystal chemical analysis of zinc 8-hydroxy-, 8-mercapto-, and 8hydroselenoquinolinates. Latvijas Ķ̄̇mijas Žurnāls, 2004, Nr. 4, 341. 350. lpp.

5. Silins E. A., Belskij V. K., Stas A. I., Asaks A. V., Pec L. A., Zaruma D. E., Bankovskij U. A. Sintez i stroenie 8-selenolhinolinata rtuti $\mathrm{Hg}\left(\mathrm{C}_{9} \mathrm{H}_{6} \mathrm{NSe}\right)_{2}$. Kristallohimiceskoe sopostavlenie 8-selenol-, 8merkapto- i 8-oksihinolinatov rtuti. Zurn. neorgan. himii, 2006, T. 51, № 1, c. 64.-70. [Russian J. of Inorg. Chem. 2006, Vol. 51, № 1, p. 57.63.].

6. Pec L.A., Bankovskij U. A., Belskij V. K., Silins E.A., Asaks A. V., Zavodnik V. E. Stroenie tris(8-selenol-, 8-merkapto- i 8-oksihinolinatov) surmy. Zurn. neorgan. himii, 2000, T. 45, № 6, c. 940.-947.

7. Silins E., Asaks A., Belakov S., Tokmakov A., Peč L., Zaruma D. Sintez i stroenie 8-selenolhinolinata vismuta $\mathrm{Bi}\left(\mathrm{C}_{9} \mathrm{H}_{6} \mathrm{NSe}_{3}\right.$. Himia geterocikl. soed., 2007, № 12, c. 1866.-1874.

8. Silins E., Belakov S., Asaks A., Tokmakov A., Pec L., Zaruma D. Sintez i stroenie 2-metil-8-selenolhinolinata platiny $\mathrm{Pt}\left[\mathrm{C}_{9} \mathrm{H}_{5}\left(\mathrm{CH}_{3}\right) \mathrm{NSe}\right]_{2}$. Himia geterocikl. soed., 2009, № 11, c. 1740.-1746. [Chem. Heterocycl.Comp., 2009, vol. 45, N 11, p. 1401.-1405.]. 
9. Silina E., Ashaks J., Belyakov S., Pech L., Zaruma D. Synthesis structure and biological activity of cadmium 2-methyl-8hydroselenoquinolinate. RTU Zinatniskie raksti. Sérija: Materiālziātne un lietišķā ķīmija. 2005, Sēj. 11, 63.- 72. lpp.

10. Pec L., Belakov S., Asaks A., Silins E., Zaruma D. Sintez i rentgenostrukturnoe issledovanie 2-metil-8-selenolhinolinata cinka i sravnitelnyj kristallohimiceskij analiz molekul 8-merkapto-, 8-selenol2-metil-8-selenolhinolinata cinka. Himia geterocikl. soed., 2007, № 1, 123.- 128. [Chem. Heterocycl. Comp., vol. 43, N 1, p. 106.-110.].

11. Silins E., Belakov S., Belskij V., Zavodnik V., Asaks A., Pec L., Zaruma D. Cintez i rentgenostrukturnoe issledovanie 2-metil-8selenolhinolinata rtuti $\mathrm{Hg}\left[\mathrm{C}_{9} \mathrm{H}_{5}\left(\mathrm{CH}_{3}\right) \mathrm{NSe}\right]_{2}$. Latvijas Kimijas Zurnals, 2005, Nr. 3, 227. - 238. lpp.

12. Silina E., Belyakov S., Ashaks J., Pech L., Zaruma D. Tris(2methylquinoline-8-selenolato-N,Se)antimony (III). Acta Crystallogr., Sec. C, Crystal Structure Commun. 2007, vol. C63, p. m62-m64. http://dx.doi.org/10.1107/S0108270106053285

13. Silins E., Belakov S., Asaks A., Tokmakov A., Pec L., Zaruma D. Cintez i rentgenostrukturnoe issledovanie 2-metil-8-hinolinselenolata vismuta $\mathrm{Bi}\left[\mathrm{C}_{9} \mathrm{H}_{5}\left(\mathrm{CH}_{3}\right) \mathrm{NSe}\right]_{3}$. Himia geterocikl. soed., 2009, № 7, c. 1080.-1086. [Chem. Heterocycl . Comp., 2009, vol. 45, N 7, p. 860.-865.].

14. Silins E., Belakov S., Asaks A., Tokmakov A., Pec L., Zaruma D. Sintez i stroenie di(2-fenil-8-hinolil)diselenida i bis[2-fenil-8-hinolil) selenolata]cinka. Himia geterocikl. soed., 2011, № 3, c. 371.-378. [Chem. Heterocycl .Comp., 2011, vol. 47, N 3, 302.-308.]

15. Silins E., Belakov S., Asaks A., Tokmakov A., Pec L., Zaruma D. Cintez i rentgenostrukturnoe issledovanie 2-fenil-8-hinolinselenolata kadmiâ. Latvijas Ķīmijas Žurnāls, 2010, Nr 1, 26.-32. lpp.

16. Sheldrick G. M. SHELXL-97, release 97-2. Program for the Refinement of Crystal Structures. Gottingen: University of Gottingen, 1998.

17. Otwinowski Z., Minor W. In: Methods in Enzimology, vol. 276, Macromolecular Crystallography. Carter, C. W., Jr. \& Sweet R, M. (eds). New York: Academic Press, 1997, p.307.-326.

18. Mackay S., Gilmore C. J., Edwards C., Stewart N., Shankland K. maXus Computer Program for the Solution and Refinement of Crystal Structures. Bruker Nonius, The Netherlands, MacScience, Japan \& The University of Glasgow, 1999.

19. Kempbel Dz. Sovremennaa obsaa himia, Moskva: Mir, 1975, tom 1, s. 415

\section{Elga Siliṇa, Jānis Ašaks, Sergejs Bel̦akovs, Andrejs Tokmakovs, Daina Zaruma. Pallādija 2,4-dimetil-8-selenolhinolināta sintēze un} uzbūve

8-selenolhinolīna un tā atvasinājumu iekšēji komplekso savienojumu veidošanās aktivitātes un k̦īmiskās saites M-Se dabas pētījumu jomā sintezēts un iegūts monokristālu veidā pallādija 2,4-dimetil-8-selenolhinolināts $\left.\mathrm{Pd}\left[\mathrm{C}_{9} \mathrm{H}_{4}\left(\mathrm{CH}_{3}\right)_{2}\right] \mathrm{SeN}\right]_{2}$ (I).

Ar rentgenstruktūranalīzes metodi (automātiskais difraktometrs Bruker-Nonius KappaCCD, $\lambda \mathrm{MoK}_{\alpha, 4} 499$ neatkarīgie refleksi ar $I>2 \sigma\left(I_{\mathrm{eksp}}\right)$, $\mathrm{R} 1=0.0477$, wR2 $=0.1182)$ noteikta savienojuma I molekulārā un kristāliskā struktūra: monoklīnā singonija, telp.gr. P2 $1 / \mathrm{n}, a=9.0092(4), b=$ $16.3290(7), c=14.1073(6) \AA, \beta=106.710(2)^{\circ}, V=1987.7(2) \AA^{3}, \mathrm{Z}=4, \rho_{\text {teorēt. }}=1.927 \mathrm{~g} / \mathrm{cm}^{3}$.

Savienojuma I kristālisko struktūru veido neitrāli asimetriski kompleksi $\left.\mathrm{Pd}\left[\mathrm{C}_{9} \mathrm{H}_{4}\left(\mathrm{CH}_{3}\right)_{2}\right] \mathrm{SeN}\right]_{2}$, kuros divi 2,4-dimetil-8-selenolhinolīna ligandi bidentāti $(\mathrm{Se}, \mathrm{N})$ koordinē pallādija atomu, veidojot kḷūdas robežās vienādus SePdN koordinācijas leṇkus $\left(84.5^{\circ}\right)$. Pallādija atoma koordinācijas poliedrs - tetraedriski izkroplots cis-kvadrāts $(2 \mathrm{Se}+2 \mathrm{~N})$, ko raksturo vienādi $\left(163.1^{\circ}\right)$ diagonālie leņki SePdN un divplaknu lenkis starp

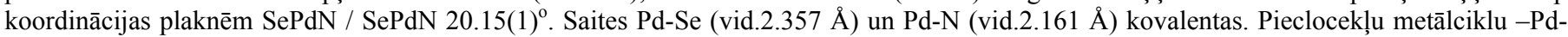
$\mathrm{Se}-\mathrm{C}(8)-\mathrm{C}(9)-\mathrm{N}$ - plāksnes ir stipri deformētas, to lauzuma divplakṇu leṇki pa līniju Se...N ir attiecīgi 22.56 un $23.44^{\circ}$.

Salīdzinot kompleksu $\mathrm{Pd}\left[\mathrm{C}_{9} \mathrm{H}_{5}\left(\mathrm{CH}_{3}\right)_{2} \mathrm{SeN}\right]_{2}$ (I) un $\mathrm{Pd}\left(\mathrm{C}_{9} \mathrm{H}_{6} \mathrm{SeN}\right)_{2}$ (II) uzbūvi, kompleksa I veidošanās saistās ar pallādija atoma koordinācijas apkārtnes $(2 \mathrm{Se}+2 \mathrm{~N})$ būtisku izmaiņu no plakanas centrsimetriskas trans- (II) uz asimetrisku tetraedriski izkroplotu cis- -kvadrātisku (I), kā arī ar saišu Pd-Se pastiprināšanos un saišu Pd-N pavājināšanos.

\section{Элга Силинь, Янис Ашакс, Сергей Беляков, Андрей Токмаков, Дайна Зарума. Синтез и строение 2,4-диметил-8- селенолхинолината палладия}

В рамках исследования комплексообразующей активности 8-селенолхинолина и его производных и природы связи Рd-Se синтезирован и получены монокристаллы 2,4-диметил-8-селенолхинолината палладия $\left.\mathrm{Pd}\left[\mathrm{C}_{9} \mathrm{H}_{4}\left(\mathrm{CH}_{3}\right)_{2}\right] \mathrm{SeN}\right]_{2}(\mathrm{I})$.

Методом рентгеноструктурного анализа (автоматический диффрактометр Bruker-Nonius KappaCCD, $\lambda \mathrm{MoK}_{\alpha}, \mathrm{R} 1=0.0477$, wR2=0.1182 для 4499 независимых отражений с $\left.I>2 \sigma\left(I_{\text {eksp. }}\right)\right)$ определена молекулярная и кристаллическая структура соединения I: моноклинная сингония, пр. гр. $\mathrm{P} 21 / \mathrm{n}, a=9.0092(4), b=16.3290(7), c=14.1073(6) \AA, \beta=106.710(2)^{\circ}, V=1987.7(2) \AA^{3}, \mathrm{Z}=4, \rho_{\text {теорег. }}=1.927 \mathrm{~g} / \mathrm{cm}^{3}$. Кристаллическая структура I состоит из нейтральных асимметричных комплексов $\left.\mathrm{Pd}\left[\mathrm{C}_{9} \mathrm{H}_{4}\left(\mathrm{CH}_{3}\right)_{2}\right] \mathrm{SeN}\right]_{2}$, где два лиганда 2,4-диметил8 -селенолхинолина бидентатно $(\mathrm{Se}, \mathrm{N})$ координируют атом палладия. Образуются одинаковые координационные углы SePdN, равные 
$2013 / 28$

$84.5^{\circ}$. Координационный полиэдр атома палладия- тетраэдрически искаженный цис-квадрат (2Se+2N), которого характеризуют одинаковые диагональные углы $\left(163.1^{\circ}\right)$ и двугранный угол между координационными плоскостями $\mathrm{SePdN} / \mathrm{SePdN}$, paвный $20.15(1)^{\circ}$. Связи Pd-Se (средн. $2.357 \AA$ ) un Pd-N (средн. $2.161 \AA$ ) ковалентные. Плоскости пятичленных металлоциклов -Pd-Se-C(8)-C(9)-Nимеют большие перегибы по линии Se...N, равные 22.56 и $23.44^{\circ}$ соответственно.

Установлено, что образование комплекса I по сравнению с комплексом $\mathrm{Pd}\left(\mathrm{C}_{9} \mathrm{H}_{6} \mathrm{SeN}\right)_{2}$ (II) сопровождается существенными изменениями координационного окружения $(2 \mathrm{Se}+2 \mathrm{~N})$ атома палладия от центросимметричного транс- квадрата в комплексе II до асимметричного тетраэдрически искаженного циис- квадрата в комплексе I, происходит также усиление связей Pd-Se и ослабление связей $\mathrm{Pd}-\mathrm{N}$. 